\title{
MENINGKATKAN HASIL BELAJAR SISWA DENGAN METODE PROBLEM BASED LEARNING MATA PELAJARAN IPS KELAS VII-4 SMP NEGERI 8 TEBING TINGGI
}

\author{
Bernat Lubis \\ Surel:bernat.lubis@yahoo.com
}

\begin{abstract}
The purpose of this study is to improve student learning outcomes in social studies subjects through the problem based learning method. This classroom action research was conducted in 2 cycles with four stages, namely: planning, implementation, observation, reflection. The subject of this study were students of class VII-4 of SMP Negeri 8 Tebing Tinggi as many as 36 students. This study used qualitative descriptive analysis techniques. Based on the data obtained from measurements in the form of learning completeness in the first cycle of $72.22 \%$ and the second cycle of $86.11 \%$ it was found that there was an increase in student learning outcomes. This means that social studies learning using the method of problem based learning can improve the learning outcomes of class VII-4 students at SMP Negeri 8 Tebing Tinggi.
\end{abstract}

Keywords : Problem Based Learning, Social Science, Learning Outcomes

\begin{abstract}
ABSTRAK
Tujuan penelitian ini untuk meningkatkan hasil belajar siswa mata pelajaran IPS melalui metode problem based learning. Penelitian tindakan kelas ini dilaksanakan sebanyak 2 siklus dengan empat tahapan yaitu : perencanaan, pelaksanaan, observasi, refleksi. Subjek penelitian ini adalah siswa kelas VII-4SMP Negeri 8 Tebing Tinggi sebanyak 36 siswa.Penelitian ini menggunakan teknik analisis dekriptif kualitatif.Berdasarkan data yang diperoleh dari pengukuran berupa ketuntasan belajar pada siklus I sebesar $72,22 \%$ dan siklus II sebesar $86,11 \%$ diketahui terdapat peningkatan hasil belajar siswa. Hal ini berarti pembelajaran IPS menggunakan m metode problem based learning dapat meningkatkan hasil belajar siswa kelas VII-4 SMP Negeri 8Tebing Tinggi.
\end{abstract}

Kata Kunci : Problem Bassed Learning, IPS, Hasil Belajar.

\section{PENDAHULUAN}

Pada dasarnya tujuan dari pendidikan IPS adalah untuk mendidik dan memberi bekal kemampuan dasar kepada siswa untuk mengembangkan diri sesuai dengan bakat, minat, kemampuan dan lingkugannya. Serta berbagai bekal untuk melanjutkan pendidikan ke jenjang yang lebih tinggi. Berdasarkan pengertian dan tujuan dari pendidikan IPS tampaknya dibutuhkan suatu pola pembelajaran yang mempu menjembatani tercapainya tujuan tersebut, kemampuan dan keterampilan guru dalam memilih dan menggunakan berbagai model, metode dan strategi pembelajaran yang harus ditingkatkan (Trianto, 2007 : 174).

Menurut rumusan NCSS, social studies adalah studi yang 
terintegrasi dari ilmu-ilmu sosial dan humaniora untuk membentuk warga negara yang baik. Mata pelajaran di sekolah merupakan sebuah studi yang terkoordinasi, sistematis yang dikembangkan atas dasar konsepkonsep displin dari ilmu antropologi, arkeologi, ekonomi, geografi, sejarah, hukum, filsafat, politik, psikologi, agama, dan sosiologi, dan juga konsep-konsep yang dibutuhkan dari ilmu alam dan matematika. IPS hanyalah sebuah program pendidikan dan bukan sub-disiplin ilmu tersendiri, sehingga tidak akan ditemukan baik dalam nomenklatur filsafat ilmu, disiplin ilmu-ilmu sosial (social sciences), maupun ilmu pendidikan (Somantri, 2001: 89).

Berdasarkan hasil observasi pembelajaran IPS diKelas VII-4SMP Negeri 8 juga terdapat kendala yang sama, yaitu materi-materi IPS diajarkan secara terpisah. Kendala yang lain. Yaitu pembelajaran yang dilaksanakan secara monoton melalui metode ceramah membuat peserta didik kurang antusias dalam menghadapi pembelajaran sehingga peserta didik jarang bertanya tentang pelajaran yang belum dipahami oleh siswa, sehingga siswa hanya mendengarkan guru menyampaikan materi pembelajaran. Hasil belajar siswa juga hanya pada tingkatan paling rendah, yaitu pada tingkatan mengingat saja karena siswa hanya menghafalkan apa yang dicatat dari guru dan yang ada dibuku paket. Untuk meningkatkan aktivitas dan pemahaman siswa di dalam kelas, maka perlu disusun strategi pembelajaran. Namun terkadang keberhasilan yang diinginkan mengalami kegagalan. Faktor yang menjadi penghambat dalam keberhasilan belajar adalah guru; kurangnya keahlian guru dalam mengelola kelas saat proses belajar mengajar, anak didik; bawaan emosional dan intelektual anak didik yang sulit menyesuaikan dengan materi pelajaran, kegiatan pengajaran, alat dan bahan evaluasi; seperangkat instrumen mengajar berupa test dan media belajar, dan suasana evaluasi; lingkungan fisik belajar (Djamarah dan Zain, 2006:109).

Berbagai permasalahan di atas memerlukan solusi yang tepat agar target pembelajaran dapat tercapai. Salah satu langkah yang akan diambil adalah menggunakan metode pembelajaran. Misalnya dengan membimbing siswa untuk bersama-sama terlibat aktif dalam proses pembelajaran dan mampu membantu siswa berkembang sesuai dengan taraf intelektualnya akan lebih menguatkan pemahaman siswa terhadap konsep-konsep yang diajarkan sehingga Siswa merasa bosan dan cepat penat sehingga menimbulkan kegaduhan.

Salah satu model pembelajaran yang dapat diterapkan adalah model pembelajaran problem based learning. Pembelajaran berbasis masalah merupakan kegiatan pembelajaran dengan cara berkelompok saling membantu membangun konsep, menyelesaikan persoalan. Pembelajaran ini 
Bernat Lubis: Meningkatkan Hasil Belajar Siswa ...

berbentuk kuantitatif maupun kualitatif. Penelitian tindakan kelas tidak menggunakan uji statistik, tetapi dengan deskriptif. Data kuantitatif yang berupa nilai dianalisis dengan menggunakan analisis deskriptif komparatif yaiu membandingkan nilai tes kondisi awal, nilai tes setelah siklus I, dan II yaitu nilai dari hasil ulangan harian siswa kelas II pada siklus I dan II. Komponen pengajaran metode problem based learning yaitu data kualitatif yang berupa observasi kegiatan guru, dan sisa serta data kuantitatif yangberupa nilai hasil ulangan harian siswa kelas II. Prosedur penelitian tindakan kelas iniada tahap perencanaan tindakan, pelaksanaan tindakan, pengamatan dan evaluasi, dan refleksi.

Sebelum mengadakan penelitian peneliti menyusun rumusan masalah, tujuan dan membuat rencana tindakan, termasuk di dalamnya instrumen penelitian dan perangkat pembelajaran.

Suatu tindakan ke dalam konteks proses belajar mengajar yang sebenarnya. Implementasi tindakan dimulai saat sebelum kegiatan dengan persiapan sebelum kegiatan dimulai, yaitu saat guru mengkondisikan siswa agar siap mengikuti pembelajaran.

\section{Siklus I}

Guru melaksanakan pembelajaran sesuai dengan langkahlangkah pembelajaran berbasis masalah. Guru mengorganisasikan siswa kepada suatu masalah dan mengorganisasikan siswa untuk belajar. Siswa mempersiapkan diri untuk menyelesaikan masalah, mencari solusi dan penjelasan. Pada kegiatan inti peneliti juga melakukan diskusi dengan kolaborator berdasarkan dengan hasil pengamatannya dengan pembelajaran PBL dan membuat rencana perbakan-perbaikan terhadap kekurangan yang ditemukan.

\section{Siklus II}

Pada siklus II ini kegiatannya hampir sama dengan siklus I namun kekurangan yang terjadi pada siklus I diperbaiki pada siklus II. Pada siklus kedua ini juga diadakan perencanaan seperti pada siklus satu yaitu tahap perencanaan, tindakan, observasi dan refleksi dalam suatu konsep yang saling terkait. Hanya saja pada siklus kedua ini adaperubahan yang menuju ke arah yang lebih baik jika dibandingkan dengan siklus satu. Hal-hal yang dianggap kurang pada siklus I diperbaiki pada siklus II.

Pengamatan dilakukan peneliti sendiri dan dibantu oleh pengamat.Pelaksanaan observasi dilakukan pada saat proses pembelajaran berlangsung dengan berpedoman pada lembar observasi yang telah dibuat oleh peneliti.

Pelaksanaan refleksi merupakan hasil observasi/ pengamatan peneliti pada saat melakukan observasi di kelas dan lingkungan sekolah yang bertujuan untuk mengevaluasi hasil tindakan yang telah dilakukan yaitu dengan menerapkan metode pembelajaran 
problem based learning. Tahapan ini menganalisis data yang diperoleh untuk memperbaiki dan menyempurnakan tindakan pada siklus selanjutnya.

Instrumen yang digunakan dalam penelitian ini adalah pedoman observasi, test hasil belajar dan kegiatan belajar mengajar. Data aktivitas belajar dan kendala yang dihadapi selama proses pembelajaran dikumpulkan melalui observasi (lembar observasi terlampir). Data hasil observasi, dan data hasil wawancara yang jenis datanya berupa pernyataan-pernyataan, dianalisis dengan menggunakan teknik analisis statistik deskriptif. Metode pengumpulan data penelitian ini adalah tertulis dan observasi. Penelitian ini dikatakan berhasil apabila siswa telah memperoleh nilai ketuntasan secara klasikal minimal $80 \%$ dari jumlah siswa dengan rumus sebagai berikut :

Persentase Ketuntasan klasikal $=$

Jumlah siswa yang tuntas $\quad$ x $100 \%$

Jumlah siswa yang mengikuti tes

\section{HASIL PENELITIAN DAN PEMBAHASAN}

Hasil data penelitian diuraikan berdasarkan siklus-siklus tindakan pembelajaran. Hasil data tersebut disesuaikan dengan masalah penelitian mencakup data perencanaan, dan proses pembelajaran. Dari hasil penelitian tindakan kelas yang telah dilakukan sebanyak dua kali pertemuan menunjukkan bahwa pengamatan yang dilakukan oleh mitra kolaborasi dan peneliti pada aktivitas guru dan siswa melalui penerapan model pembelajaran problem based learning pada mata pelajaran IPS kelas VII-4 SMP Negeri 8 Tebing Tinggi.

Hasil analisis pengamatan peneliti dari tindakan pra siklus, siklus I dan siklus II pada Tabel 1 terjadi peningkatan hasil belajar siswa. Hal ini dapat dilihat dengan peningkatan jumlah siswa dari 22 siswa yang tuntas belajar pada pra siklus menjadi 31 siswa yang tuntas belajar metode pembelajaran PBL pada siklus II.

Tindakan siklus I dengan menggunakan model pembelajaran PBL, Selama pembelajaran berlangsung, guru kelas selaku mitra kolaborasi melakukan pengamatan tentang kegiatan pembelajaran yang dilakukan dan keterampilan siswa dalam bertanya. Nilai rata-rata kelas pembelajaran siklus I menunjukkan peningkatan bila dibanding dengan pra tindakan ke siklus I, yaitu dari 70,5 menjadi 71,8 . Nilai maksimal 90 dan nilai minimal 60 dengan ratarata nilai UH I adalah 71,8. Sementara persentase ketuntasan belajar siswa yang telah mencapai KKM dari pra tindakan meningkat dari $61,11 \%$ menjadi $72,22 \%$ pada siklus I. Hasil belajar siswa pada siklus I masih belum sesuai dengan persentase ketuntasan belajar siswa meskipun begitu terdapat peningkatan hasil belajar siswa dari prasiklus ke siklus I.

Pada siklus I hasil belajar belum bisa dikatakan berhasil karena 
belum memenuhi kriteria ketuntasan. Hal tersebut dikarenakan pada saat pelaksanaan pembelajaran ada beberapa siswa yang pasif, karena Banyak siswa ragu-ragu dan kurang percaya diri untuk bertanya, memberi pendapat, dan menjawab pertanyaan. Selain itu Suasana kelas ramai dan banyak siswa yang tidak memperhatikan penjelasan guru maupun memperhatikan teman atau siswa lain yang mengeluarkan pendapat. Hasil refleksi yaitu berupa temuaan tingkat orientasi siswa pada masalah. Siswa tidak fokus saat guru menentukan suatu masalah sehingga beberapa siswa masih terlihat bingung dalam membentuk kelompok belajar. Refleksi dari guru sebagai peneliti adalah peneliti harus lebih berinteraksi lagi dengan siswa dan menjelaskan semua materi yang belum jelas bagi siswa, selain itu peneliti sebaiknya memberikan reward kepada siswa atau kelompok yang mempresentasikannya dengan baik.

Kekurangan pada siklus I diperbaiki pada siklus II. Pada siklus II ketuntasan belajar siswa meningkat menjadi $86,11 \%$. Terjadi peningkatan $13,89 \%$ dari siklus I.setelah mendapatkan metode pembelajaran model pembelajaran PBL.Pada siklus II hanya 5 (lima) siswa yang belum memenuhi KKM atau $31(86,11 \%)$ siswa sudah tuntas belajar. Pada siklus II siswa sudah terlihat terdapat peningkatan keaktifan dan ketepatan dalam menemukan pasangan jawaban yang tepat.
Siklus II mengalami perubahan dari aspek kognitif dan aspek afektif. Pelaksanaan tindakan kelas pada siklus II berjalan dengan baik dan lancar. Siswa sudah menunjukkan keaktifannya dalam pembelajaran. Dengan penerapan PBL siswa menyelesaikan masalah, berani mengajukan pertanyaan dan akhirnya siswa dapat meningkatkan kemampuan kognitifnya. Dapat dikatakan bahwa penggunaan mettode melibatkan pembelajaran aktif pada siswa. Hal ini sesuai dengan pendapat Al-Tabany (2014:63) pembelajaran berbasis masalah merupakan kegiatan pembelajaran dengan cara berkelompok saling membantu membangun konsep, menyelesaikan persoalan. Pembelajaran ini didasarkan pada prinsip menggunakan masalah sebagai titik awal akuisisi dan inetgrasi pengetahuan baru.

\section{Pembahasan}

Dalam proses pembelajaran, PBL dirancang secara sistematis untuk meningkatkan minat dan motivasi pembelajaran agar mutu dan kualitas belajarnya semakin maju dansemakin aktif berperan dalam aktivitas proses pembelajaran, sehingga nantinya dapat meningkatkan kualitas hasil belajarnya. Dalam proses pembelajaran terdapat pesan-pesan yang harus dikomunikasikan kepada siswa. Pesan tersebut merupakan isi dari suatu topik pembelajaran. Banyak cara yang dapat digunakan 
guru untuk menyampaikan pesan, salah satunya dengan menerapkan model pembelajaran problem based learning.

Siklus II ditujukan untuk memperbaiki kekurangan yang terjadi pada siklus I berdasarkan hasil refleksi siklus I. Dalam perbaikan ini diharapkan siswa menjadi lebih aktif dalam proses pembelajaran dan hasil belajar siswa dapat meningkat sesuai target yang akan dicapai. Pada siklus II ini ada peningkatan dan ketertarikan siswa untuk belajar IPS sehingga prosespembelajaran berlangsung baik dan menyenangkan. Siswa sudah terlihat terdapat peningkatan keaktifan danketepatan dalam menemukan pasangan jawaban yang tepat.

Dengan melihat indikator yangt telah ditetapkan sebelumnya, hasil yang diperoleh telah mencapai lebih dari batas minimal indikator keberhasilan sehingga penelitian tidak perlu dilanjutkan lagi untuk siklus berikutnya. Oleh karena itu dapat disimpulkan bahwa proses pembelajaran dengan problem based learning sangat sesuai dengan mata pelajaran IPS, maka Penelitian Tindakan Kelas (PTK) ini bisa dikatakan berhasil karena hasil peningkatan proses pembelajarannya optimal.

Menurut Ngalimun (2012:89), pembelajaran berbasis masalah merupakan salah satu model pembelajaran inovatif yang dapat memberikan kondisi belajar aktif kepada siswa. Masalah yang diberikan pada problem based learning digunakan untuk mencari solusi dari permasalahan dunia nyata. Masalah yang diberikan ini digunakan untuk mengikat peserta didik pada rasa ingin tahu pada pembelajaran yang dimaksud.

Siswa merasa lebih cepat mengerti dengan pendekatan pembelajaran yang digunakan. Metode problem based learning terbukti meningkatkan hasil belajar siswa, terlihat dari hasil persentase ketuntasan belajar siswa yang mengalami peningkatan dari prasiklus, siklus I hingga siklus II.

\section{SIMPULAN}

Simpulan dari hasil penelitian diatas adalah penggunaan metode pembelajaran PBL mata pelajaran IPSdi kelas VII-4SMP Negeri 8 Tebing Tinggi tahun pelajaran 2018/2019 berdampak positif dalam meningkatkan aktivitas dan hasil belajar siswa setiap siklusnya. Hal tersebut dapat dilihat dari peningkatan persentase ketuntasan belajar siswa pada siklus I (72,22 \%), siklus II $(86,11 \%)$.

\section{DAFTAR RUJUKAN}

Abidin Y. 2016. Desain Pembelajaran Dalam Konteks Kurikulum 2013. Bandung: PT. Refika Aditama.

Al-Tabany, T.I.B. 2014. Mendesain Model Pembelajaran Inovatif, Progresif dan Kontekstual. Jakarta: Prenadamedia. 
Bernat Lubis: Meningkatkan Hasil Belajar Siswa ...

Daryanto. 2013. Pendekatan Saintifik

Kurikulum. Yogyakarta: Gava Media.

Djamarah dan Zain. 2006. Strategi Belajar Mengajar. Jakarta: PT. Rineka Cipta.

Ngalimun. 2012. Strategi dan Model Pembelajaran. Yogyakarta: Aswaja Pressindo.

Rusman. 2011. Model-Model Pembelajaran Mengembangkan Profesional Guru. Jakarta: Rajawali Pres.

Somantri, M.N. 2001. Menggagas Pembaharuan Pendidikan IPS. Bandung: Remaja Rosdakarya.

Trianto. 2007. Model-Model Pembelajaran Inovatif Berorientasi Konstruktivistik Konspe Landasaran TeoritisPraktis dan Implementasinya. Jakarta: Prestasi Pustaka.

Taniredja, T., E. Miftah, S. Harmianto. 2013. Model-Model Pembelajaran Inovatif dan Efektif. Bandung: Alfabeta. 